\title{
The growth and sugar utilization by Lactobacillus delbrueckii ssp. bulgaricus and Streptococcus salivarius ssp. thermophilus isolated from market yogurt
}

\author{
M.J. Amoroso ${ }^{1}$, M.C. Manca de Nadra ${ }^{1,2}$ and G. Oliver ${ }^{1,2^{*}}$ \\ 1 Universidad Nacional de Tucumán, Facultad de Bioquimica, Quimica y Farmacia; \\ ${ }^{2}$ Centro de Referencia para Lactobacilos (CERELA), Chacacubo 145, 4000 Tucumán, Argentina
}

(received 3 October 1988, accepted 27 April 1989)

Summary - Lactobacillus delbrueckii ssp. bulgaricus Yop 12 and Streptococcus salivarius ssp. thermophilus Yop 9 were isolated from a commercial yogurt of Argentina. Significant differences in growth response to glucose, galactose, fructose, lactose and sucrose were found among these strains in pure and mixed cultures. The development and sugars utilization by these strains are completely different from those found in Lactobacillus delbrueckii ssp. bulgaricus $\mathrm{Ss}_{1}$ and Streptococcus salivarius ssp. thermophilus $\mathrm{Ss}_{2}$ isolated from another market yogurt of Argentina. In mixed cultures only with glucose as carbon source there is an increase of growth. Lactobacillus delbrueckii ssp. bulgaricus Yop 12 is unable to ferment galactose and sucrose in pure culture. When combined with Streptococcus salivarius ssp. thermophilus Yop 9, Lactobacillus delbrueckii ssp. bulgaricus Yop 12 acquires capacity to grow with galactose. In milk cultures there is a stimulation of growth of both microorganisms. In basal medium with lactose we observed a decrease of growth in Lactobacillus delbrueckii ssp. bulgaricus and Streptococcus salivarius ssp. thermophilus. In the presence of fructose or sucrose there is an inhibition of growth of both microorganisms in mixed cultures. Sugars concentrations were measured using high pressure liquid chromatography.

Lactobacillus delbrueckil ssp. bulgaricus - Streptococcus salivarius ssp. thermophilus yogurt - growth and sugar utilization

Résumé - Croissance et utilisation des sucres par des souches de Lactobacillus delbrueckii ssp. bulgaricus et Streptococcus salivarius ssp. thermophilus isolées de yaourt du commerce. Lactobacillus delbrueckii ssp. bulgaricus Yop 12 et Streptococcus salivarius ssp. thermophilus Yop 9 ont été isolés à partir de yaourt commercial produit en Argentine. Les taux de croissance des souches étaient significativement différents selon que les souches étaient ensemencées séparément ou en mélange dans les cultures contenant les sucres suivants : glucose, galactose, fructose, lactose ou saccharose. Les souches Lactobacillus delbrueckii ssp. bulgaricus Ss1 et Streptoccus salivarius ssp. thermophilus $\mathrm{Ss}_{2}$ isolées d'une autre source de yaourt commercial ont un comportement différent pour l'utilisation des sucres et le taux de croissance. Dans les cultures mixtes avec glucose uniquement il y a une augmentation du taux de croissance. Lactobacillus delbrueckii ssp. bulgaricus Yop 12 n'est pas capable de fermenter le saccharose quand il est cultivé tout seul. Quand il est mélangé avec Streptoccus salivarius ssp. thermophilius Yop 9, Lactobacillus

\footnotetext{
* Correspondence and reprints.
} 
delbrueckii ssp. bulgaricus Yop 12 a la capacité de croitre dans un milieu contenant du galactose. Dans les cultures sur lait il y a une stimulation pour les deux souches. Sur un milieu de base avec lactose nous avons trouvé une diminution du taux de croissance pour Lactobacillus delbrueckii ssp. bulgaricus et Streptococcus salivarius ssp. thermophilus; quand le fructose ou le saccharose sont présents il y a une inhibition du taux de croissance des deux microorganismes dans les cultures mixtes. Les concentrations des sucres ont été mesurées par HLPC.

Lactobacillus delbrueckii ssp. bulgaricus - Streptococcus salivarius ssp. thermophilus yaourt - croissance - utilisation des sucres

\section{INTRODUCTION}

Yogurt is a fermented milk product made with Streptococcus salivarius ssp. thermophilus and Lactobacillus delbrueckii ssp. bulgaricus and it has become a highly popular food over the last 15 years. These two organisms have a symbiotic relationship during the manufacture of yogurt (Bautista et al., 1966; Galesloot et al., 1968; Veringa et al., 1968; Radke-Mitchell \& Sandine, 1984). In the present text these organisms will be referred to as $S$. thermophilus and $L$. bulgaricus; however, the ratio of the yogurt cultures may range between 1:1-3:1 (Schulz \& Hingst, 1954).

Yogurt is an excellent source of protein and the suggested role of the Lactobacillus species is to degrade casein, providing the non-proteolytic $S$. thermophilus with a source of peptides and amino-acids (Bautista et al., 1966; Accolas et al., 1971). This is important because the free aminoacids found in milk are in very low concentrations (Thomas \& Mills, 1981; Marshall \& Law, 1984). Production of formic acid (Galesloot et al., 1968) or carbon dioxide (Driessen et al., 1982) by streptococci has been reported to stimulate $L$. bulgaricus.

The sugar fermentation pattern in milk products containing $S$. thermophilus and $L$. bulgaricus led Turner et al. (1983) to suggest another important role of the lactobacilli. They observed that the major role of the thermophilic lactobacilli in Swiss-type cheese is to metabolize the galactose which the $S$. thermophilus culture cannot utilize. Some strains of $S$. thermophilus are unable to ferment galactose (gal-) and utilize only the glucose portion of lactose, releasing free galactose into the extracellular medium (O'Leary \& Woychik, 1976; Tinson et al., 1982; Thomas \& Crow, 1984; Hutkins et al., 1985a)

Some yogurt manufacturers believe consumers of plain yogurt prefer a slightly sweetened product and the sweeteners used in the manufacture of the Swiss-style yogurt were sucrose and fructose (Mc Gregor \& White, 1986, 1987). The aim of this work was to determine the characteristics of $S$. thermophilus and $L$. bulgaricus (pure and mixed cultures) isolates from commercial yogurt of Argentina to grow and to utilize sugar in order to carry out a comparative study with the results obtained by Amoroso et al. (1988) with $S$. thermophilus $\mathrm{Ss}_{2}$ and $L$. bulgaricus $\mathrm{Ss}_{1}$ isolated from another commercial source.

\section{MATERIALS AND METHODS}

\section{Microorganisms}

L. bulgaricus Yop 12 and S. thermophilus Yop 9 were isolated from a commercial yogurt in Argentina by Raya et al. (1986). These strains were preserved in LAPTg agar medium at $4{ }^{\circ} \mathrm{C}$ and lyophilized. For use, the strains were activated by 2 daily transfers in LAPTg medium for 3 days, starting the experiments with a 12-h-old culture. 


\section{Culture medium and growth conditions}

The basal medium for the growth of these microorganisms was that described by Raibaud et al. (1961). The $\mathrm{pH}$ was adjusted to 6.5 with $0.2 \mathrm{~N}$ $\mathrm{NaOH}$. Glucose, fructose, galactose, sucrose and lactose were added to the medium at the concentrations indicated in each experiment. The basal medium was sterilized by autoclaving for $20 \mathrm{~min}$ at $118^{\circ} \mathrm{C}$. The sugars were sterilized by filtration. Lactic acid production was measured by growing the cultures in sterile reconstituted skim-milk powder free from antibiotics (a solution was used of $10 \%$ total solids autoclaved at $121^{\circ} \mathrm{C}$ for $10 \mathrm{~min}$ ). In mixed cultures the inoculation rate was $1: 1$ ( $L$. bulgaricus : $S$. thermophilus).

\section{Enumeration of microorganisms}

S. thermophilus and L. bulgaricus were counted by surface spreading $0.1 \mathrm{ml}$ samples on the LAPTg agar medium with the following composition : $1.0 \%$ yeast extract, $1.5 \%$ peptone, $1.0 \%$ tryptone, $1.0 \%$ glucose, $0.1 \%$ Tween 80 and 2.0 agar, and by direct microscopic count in the Newbauer chamber.

\section{Developed acidity}

Sterile skim milk samples $(5 \mathrm{ml})$ withdrawn from the culture flask at regular intervals were titrated with $0.1 \mathrm{~N} \mathrm{NaOH}$ using phenolphthalein as colour indicator. The percentage of developed acidity was calculated as lactic acid; $\mathrm{pH}$ measurements were carried out using a $\mathrm{pH}$ meter $\mathrm{pH}$ MD.

\section{Quantification of glucose, fructose and sucrose by high performance liquid chromatography (HPLC)}

The cultures were centrifuged at $3000 \mathrm{rpm}$ for $20 \mathrm{~min} ; 0.5 \mathrm{ml}$ of each supernatant was diluted (4-fold) with acetonitrile- $\mathrm{H}_{2} \mathrm{O}$ (85:15). After 10 min at $4{ }^{\circ} \mathrm{C}$ it was centrifuged at $3000 \mathrm{rpm}$ for
$10 \mathrm{~min}$. The supernatant was filtered through $0.45 \mu \mathrm{m}$ filter paper and the concentration measured using high performance liquid chromatography (HPLC) on a Water's Associates (Milford (MA) USA) chromatograph. A model R 401 refractive index detector and a carbohydrate analysis column were used. The oven was heated to room temperature. The mobile phase was acetonitrile $-\mathrm{H}_{2} \mathrm{O}(85: 15)$. A flow rate of $1.5 \mathrm{ml} / \mathrm{min}$ was used; $1 \%$ glucose, fructose or sucrose were used as internal standard. Glucose plus galactose were not resolved in our experimental conditions.

Glucose plus galactose were estimated by the method of Nelson \& Somogyi (1966) and glucose concentration was determined by the glucose oxidase method (Glucostat, Worthington Diagnostic, Worthington Biochemical Corporation, Free Hold, NJ 07728, USA).

\section{RESULTS AND DISCUSSION}

The optimum growth temperature for $L$. bulgaricus Yop 12 was $45^{\circ} \mathrm{C}$ and for $S$. thermophilus Yop $940-45^{\circ} \mathrm{C}$. The optimum temperature for mixed culture was $45^{\circ} \mathrm{C}$. These results are similar to the data reported by Amoroso et al. (1988) for these strains isolated from another commercial yogurt. The growth of our cultures at a different initial $\mathrm{pH}$ in LAPTg medium shows that the optimum $\mathrm{pH}$ for pure and mixed cultures occurred at 6.8.

Figure 1 ( $a$ and $b$ ) shows the relationship between growth, developed acidity and $\mathrm{pH}$ in $S$. thermophilus, $L$. bulgaricus and mixed culture with $0.5 \%$ of each strain in sterile skim milk medium. Both microorganisms grow similarly in pure cultures (Fig. 1 a) and the acid production by $L$. bulgaricus is higher than that of $S$. thermophilus (Fig. $1 \mathrm{~b}$ ).

The $\mathrm{pH}$ changes from 6.6 to 4.4 in $8 \mathrm{~h}$ of growth and at the same time the acid production increases up to $0.6 \%$ (Fig. 1 b). 

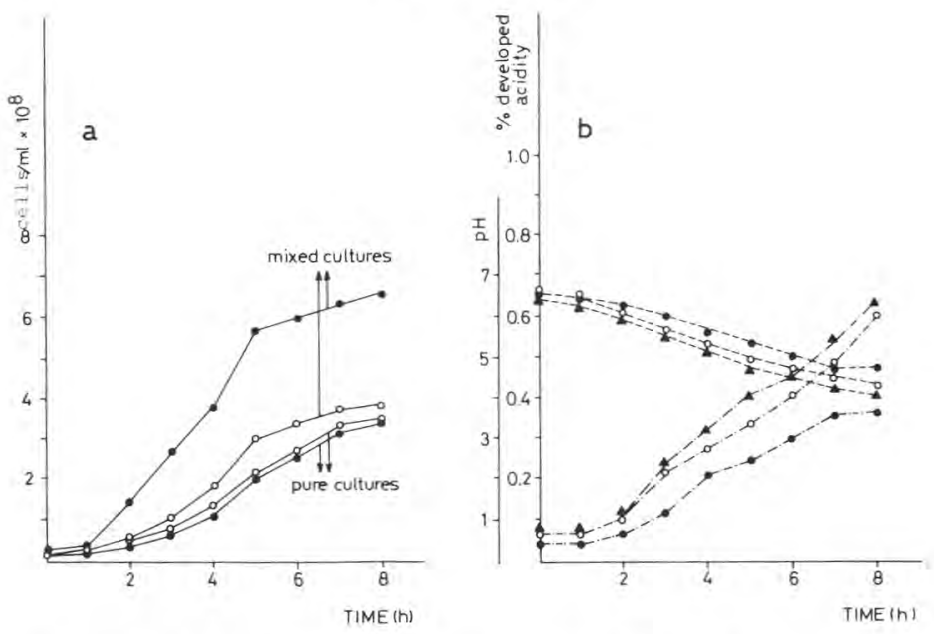

Fig. 1. Growth (a), developed acidity (-०--) and $\mathrm{pH}(---)$ (b) of pure and mixed cultures of L. bulgaricus and $S$. thermophilus in milk at $37^{\circ} \mathrm{C}$. S. thermophilus (e); L. bulgaricus (O); mixed culture (A). Croissance (a), acidité développée (-a.-) et pH (- - ) (b) de cultures pure et mixte de L. bulgaricus et $\mathrm{S}$. thermophilus dans du lait à $37^{\circ} \mathrm{C}$.

In mixed culture stimulation of growth in both microorganisms is observed and the increase of $S$. thermophilus is higher than that of L.bulgarius (Fig. $1 \mathrm{a}$ ). Moon \& Reinbold (1976) have shown that stimulation of acid production in mixed culture is due to enhanced growth of streptococci. Accolas et al. (1977) reported that the stimulant effect of a strain upon the other can be observed by acid production. These results are different from those reported by Amoroso et al. (1988) with strains isolated from another commercial yogurt.

\section{Growth and sugar utilization}

In LAPT-glu medium (1\% glucose) L. bulgaricus and $S$. thermophilus grow similarly (Fig. 2 a). In mixed culture both microorganisms increased their growth : $S$. thermophilus from $2.3 \times 10^{8} \mathrm{cells} / \mathrm{ml}$ to $3.3 \times$
$10^{8}$ cells $/ \mathrm{ml}$, and $L$. bulgaricus from $2.28 \times$ $10^{8} \mathrm{cells} / \mathrm{ml}$ to $3.6 \times 10^{8} \mathrm{cells} / \mathrm{ml}$ in $5 \mathrm{~h}$ of incubation at $37^{\circ} \mathrm{C}$. There is a mutualistic effect. With the strains isolated from another commercial yogurt the results reported by Amoroso et al. (1988) showed that $L$. bulgaricus growth was more active than $S$. thermophilus in pure culture in this time. In LAPT-gal medium ( $1 \%$ galactose) L.bulgaricus does not grow and $S$. thermophilus grows poorly (Fig. 2 b). In mixed cultures, $L$. bulgaricus acquires capacity to grow in LAPT-gal and $S$. thermophilus grows more actively. The unability of many commercial strains of $S$. thermophilus and $L$. bulgaricus to utilize galactose has practical implications in a number of fermented dairy products. Thomas \& Crow (1984) and Hutkins et al. (1985a) have shown that enzymes of the Leloir pathway are either not inducible or permanently repressed in gal- strains of $S$. thermophilus. The galactose transport occurred via a gal $P$, which was also present in gal- strains, but this activity was very low and was de- 



Fig. 2. Growth of $S$. thermophilus $(\bullet)$ and $L$. bulgaricus $(O)$ in pure and mixed cultures in LAPT-glu (a), LAPT-gal (b) and LAPT-lac (c) at $37^{\circ} \mathrm{C}$. Croissance de $S$. thermophilus $(\bullet)$ et $L$. bulgaricus $(O)$ en cultures pure et mixte en milieu LAPT-glu (a), LAPT-gal (b) et LAPT-lac (c) à $37^{\circ} \mathrm{C}$. 
pendent on an exogenous energy source. Hutkins et al. (1985b) suggest the possibility that some sugars may be bound but not transported by the sugar transport systems in $S$. thermophilus. It is possible that some metabolic products of these $L$. Bulgaricus and $S$. thermophilus strains in mixed culture permit to the strains to utilize galactose. In the study with the strains isolated from another commercial source (Amoroso et al., 1988) in mixed culture $L$. bulgaricus grows more actively. In LAPTXac ( $1 \%$ lactose) single strains of $L$. bulgaricus and $S$. thermophilus have a similar growth pattern and in mixed culture there is an inhibition of growth which is higher in L. bulgaricus than in S. thermophilus (Fig. $2 \mathrm{c}$ ). Lactose is hydrolysed inside the bacterial cell by the $\beta$-galactosidase enzyme to glucose and galactose. Both microorganisms utilize glucose but galactose is poorly consumed by these strains in mixed culture. It appears that galactose accumulated in the culture medium may produce an inhibition of $\beta$-galactosidase enzyme with a consequent diminution of growth. Bacteria display a remarkable capacity to regulate synthesis of enzyme systems with varying growth conditions. These results are different from those found for the strains isolated from another commercial yogurt (Amoroso et al., 1988) (in mixed culture there is a growth stimulation which is higher in S. thermophilus than in L. bulgaricus).

The results obtained in milk medium show an increase of growth in both microorganisms in mixed culture (Fig. 1 a). It is known that the lactose utilization for growth of L. bulgaricus and S. thermophilus in mixed culture depends on the characteristics of the basal medium and we are investigating the effect of different components of LAPT-lac medium on the growth of these microorganisms in milk medium. O'Leary \& Woychik (1976) reported one strain of $S$. thermophilus which can simul- taneously utilize lactose and glucose in lactose-hydrolyzed milk but only used lactose in broth containing glucose and lactose.

In LAPT-fru medium ( $1 \%$ fructose) $L$. bulgaricus grows more actively than $S$. thermophilus. In mixed culture both microorganisms decreased growth (Fig. $3 \mathrm{a}$ ), for example the $L$. bulgaricus viable count decreased from $28 \times 10^{7}$ cells $/ \mathrm{ml}$ to $22 \times 10^{7}$ cells $/ \mathrm{ml}$ and $S$. thermophilus from $20 \times 10^{7}$ cells $/ \mathrm{ml}$ to $13 \times 10^{7}$ cells $/ \mathrm{ml}$ after $5 \mathrm{~h}$ of incubation at $37^{\circ} \mathrm{C}$. In LAPT-suc medium (1\% sucrose) only $S$. thermophilus grows in pure and mixed cultures and no growth was observed for L. bulgaricus (Fig. 3 b).

In LAPT-glu + gal $(0.5 \%$ glucose and $0.5 \%$ galactose) both microorganisms grow similarly but in mixed culture there is an inhibition of growth of the two strains (Fig. 4 a). It is a typical case of inhibition by substrate competition. In the strains isolated by Amoroso et al. (1988) the response of growth in LAPT-glu + gal medium is different.

The utilizations of glucose, galactose and lactose by $L$. bulgaricus and $S$. thermophilus in pure and mixed cultures are represented in Table I. Galactose concentration is not modified in the medium with L. bulgaricus but in mixed culture this sugar concentration diminished more than in pure culture of $S$. thermophilus. These results are the same as those found for the strains isolated for the other commercial yogurts (Amoroso et al., 1988). Lactose concentration in mixed culture decreased by $2.3 \mathrm{~g} / \mathrm{l}$ in $8 \mathrm{~h}$ of incubation. In pure cultures of $L$. bulgaricus and $S$. thermophilus over the same period the concentration of this sugar decreased by $0.25 \mathrm{~g} / \mathrm{l}$ and 0.30 $\mathrm{g} / \mathrm{l}$, respectively. The response of growth of $L$. bulgaricus and $S$. thermophilus in LAPT-lac shows that in mixed culture there is an example of amensalism in which the growth of one species is inhibited by the presence of the other. 
Table II shows the results of glucose + galactose utilization in a culture medium $(0.5 \%$ glu $+0.5 \%$ gal). The consumption of glucose is more rapid in L. bulgaricus than in $S$. thermophilus and in mixed culture the residual glucose and galactose is higher than in pure culture.

In LAPT-fru + glu medium $(0.5 \%$ glucose $+0.5 \%$ fructose) both microorganisms grow more actively than in LAPT-fru medium, and in mixed culture we can observe growth inhibition of both microorganisms (Fig. 4b). It can be observed that fructose utilization is not inhibited by glucose and that in mixed culture there is again a growth inhibition by substrate competition.

Table I. Utilization of glucose, galactose and lactose* by $L$. bulgaricus and Str. thermophilus in pure and mixed cultures.

Utilisation de glucose, galactose et lactose* par L. bulgaricus et Str.) thermophilus dans cultures pures et mixtes.

\begin{tabular}{llll}
$\begin{array}{l}\text { Sugar } \\
\text { Utilization }\end{array}$ & Time & \multicolumn{2}{c}{ Cultures } \\
& (h) & $\begin{array}{l}\text { L. bulga- Str. ther- Mixed } \\
\text { ricus }\end{array}$ \\
& & mophilus Culture
\end{tabular}

$\begin{array}{lllrl}\text { Glucose } & 0 & 10.0 & 10.0 & 10.0 \\ & 2 & 5.0 & 6.0 & 4.0 \\ & 4 & 2.0 & 3.4 & 1.7 \\ & 6 & 0.85 & 1.4 & 0.8 \\ & 8 & 0.67 & 0.9 & 0.17\end{array}$

$\begin{array}{rrrr}\text { Galactose } & 0 & 10.0 & 10.0 \\ & 2 & 8.6 & 6.6 \\ 4 & 7.0 & 4.7 \\ 6 & 6.7 & 4.1 \\ 8 & 6.5 & 3.3\end{array}$

$\begin{array}{lllrr}\text { Lactose } & 0 & 10.0 & 10.0 & 10.0 \\ & 2 & 2.0 & 3.0 & 6.9 \\ & 4 & 1.2 & 1.8 & 3.5 \\ & 6 & 0.31 & 0.5 & 2.9 \\ & 8 & 0.25 & 0.3 & 2.3\end{array}$

" Sugar concentrations determined by HPLC are expressed as $\mathrm{g} / \mathrm{l}$.

Values are means of three samples.
The utilization of fructose, glucose + fructose and sucrose by $L$. bulgaricus and $S$. thermophilus is represented in Table III. Sucrose concentration is not modified in the medium with $L$. bulgaricus and in mixed culture the sugar concentration is $1.9 \mathrm{~g} / \mathrm{l}$ after $8 \mathrm{~h}$ of incubation at $37^{\circ} \mathrm{C}$.

From these results it can be seen that there are differences in the behavior of strains isolated from two commercial sources of yogurt, as a result of different intracellular control strategies. The mixed cultures of $S$. thermophilus and L. bulgaricus isolated by Amoroso et al. (1988) showed growth stimulation in respect to pure cultures in medium with glu-

Table II. Utilization of glucose + galactose* by $L$. bulgaricus and Str. thermophilus in pure and mixed cultures.

Utilisation de glucose plus galactose* par L. bulgaricus et Str. thermophilus dans cultures pures et mixtes.

\section{Sugar Time Cultures}

Utilization (h) L. bulga- Str. ther- Mixed ricus mophilus Culture

$\begin{array}{lllll}\text { Total } & 0 & 1.0 & 1.0 & 1.0 \\ \text { sugars } & 2 & 0.79 & 0.75 & 0.81 \\ & 4 & 0.69 & 0.62 & 0.76 \\ & 6 & 0.53 & 0.55 & 0.64 \\ & 8 & 0.50 & 0.52 & 0.60\end{array}$

$\begin{array}{lllll}\text { Residual } & 0 & 0.50 & 0.49 & 0.48 \\ \text { glucose } & 2 & 0.22 & 0.25 & 0.34 \\ & 4 & 0.18 & 0.17 & 0.24 \\ & 6 & 0.04 & 0.11 & 0.11 \\ & 8 & 0.01 & 0.10 & 0.03\end{array}$

$\begin{array}{lllll}\text { Residual } & 0 & 0.50 & 0.50 & 0.50 \\ \text { galactose } & 2 & 0.50 & 0.49 & 0.50 \\ & 4 & 0.50 & 0.45 & 0.49 \\ & 6 & 0.50 & 0.43 & 0.46 \\ & 8 & 0.50 & 0.41 & 0.45\end{array}$

* Sugar concentrations are expressed as g\%. Total sugars determined by Nelson-Somogyi method. Residual glucose determined by the glucose oxidase method. Values are means of three samples. 
Table III. Utilization of fructose, glucose + fructose and sucrose by L. bulgaricus and Str. thermophilus in pure and mixed cultures.

Utilisation de fructose, glucose plus fructose et saccharose par L. bulgaricus et Str. thermophilus dans cultures pures et mixtes.

$\begin{array}{lllll}\text { Sugar } & \text { Time } & & \text { Cultures } & \\ \text { Utilization } & \text { (h) } & \text { L. bulgaricus } & \text { Str. thermophilus } & \text { Mixed Culture }\end{array}$

\begin{tabular}{lrrrr}
\hline Fructose & 0 & 10.0 & 10.0 & 10.0 \\
& 2 & 6.9 & 8.6 & 8.7 \\
& 4 & 5.2 & 7.4 & 7.9 \\
& 6 & 2.7 & 5.6 & 6.1 \\
& 8 & 2.0 & 4.6 & 5.2
\end{tabular}

\begin{tabular}{llllllll} 
& \multicolumn{1}{c}{ glu - fru } & \multicolumn{2}{c}{ glu - fru } & \multicolumn{2}{c}{ glu - fru } \\
Glucose & 0 & 5.0 & 5.0 & 5.0 & 5.0 & 5.0 & 5.0 \\
+ fructose & 2 & 2.1 & 2.4 & 2.8 & 2.6 & 4.6 & 4.1 \\
& 4 & 1.5 & 1.7 & 1.6 & 1.5 & 1.9 & 1.8 \\
& 6 & 1.0 & 1.2 & 1.5 & 1.3 & 1.6 & 1.7 \\
& 8 & 0.7 & 0.9 & 1.3 & 1.0 & 1.4 & 1.6
\end{tabular}

Sucrose

\begin{tabular}{|c|c|c|c|c|c|c|}
\hline \\
\hline & & & & & & \\
\hline & 1.5 & 0.9 & 4.9 & 2.1 & 0.2 & 5.2 \\
\hline & 0.46 & 0.08 & 1.6 & 0.97 & 0.17 & 2.5 \\
\hline & 0.28 & 0.07 & 1.3 & 0.87 & 0.12 & 2.0 \\
\hline & & & & & & \\
\hline
\end{tabular}

* Sugar concentrations determined by HPLC are expressed as g/l. Values are means of three samples.
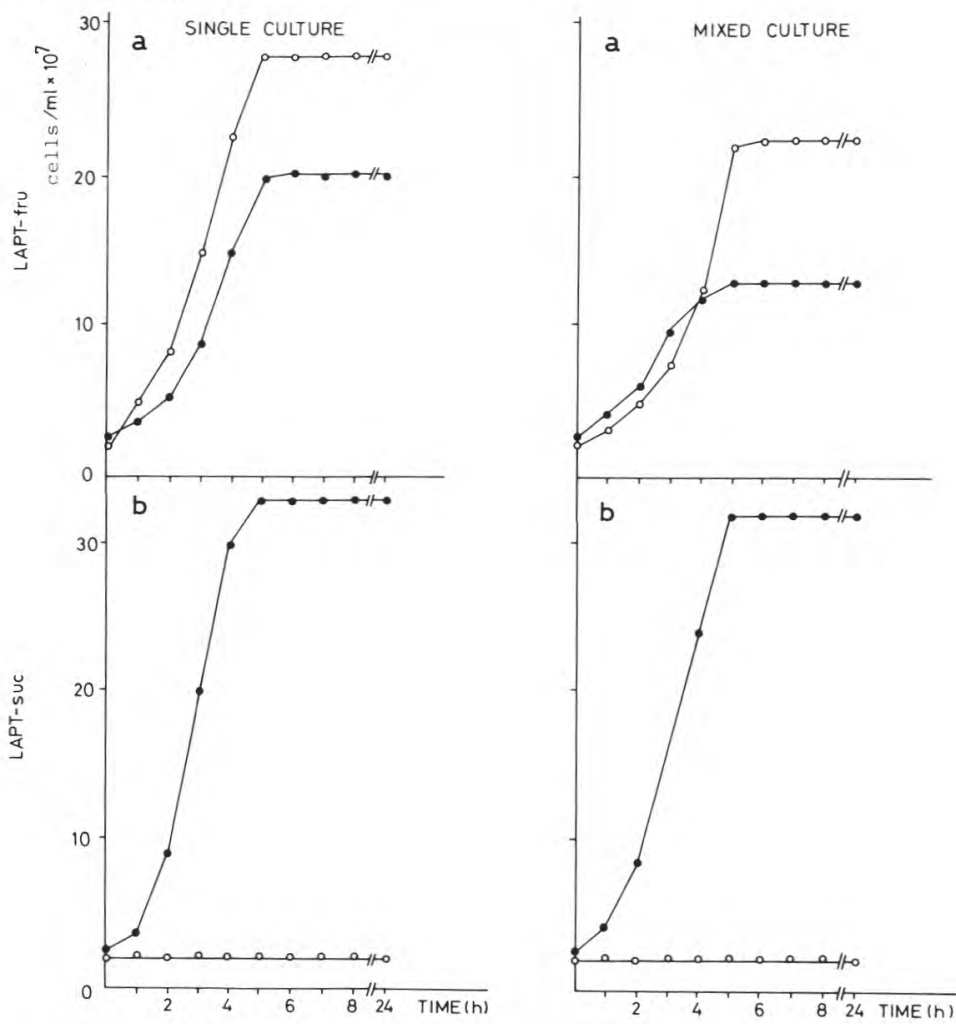

Fig. 3. Growth of $S$. thermophilus $(\bullet)$ and L. bulgaricus $(O)$ in pure and mixed cultures in LAPT-fru (a) and LAPT-suc (b) at $37^{\circ} \mathrm{C}$.

Croissance de $\mathrm{S}$. thermophilus $(\bullet)$ et $\mathrm{L}$. bulgaricus $(O)$ en cultures pure et mixte en milieu LAPT-fru (a) et LAPT-suc (b) à $37^{\circ} \mathrm{C}$. 

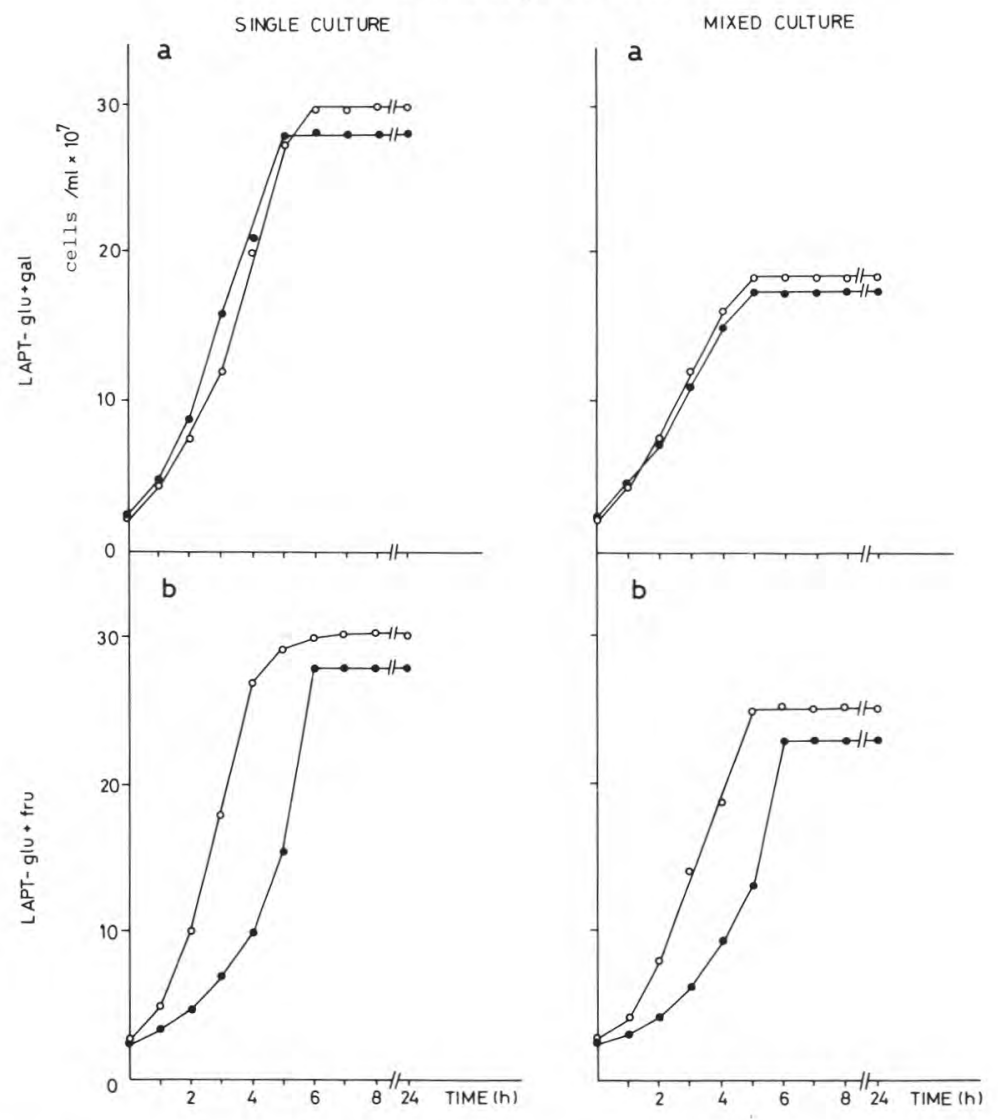

Fig. 4. Growth of S. thermophilus $(\bullet)$ and $L$. bulgaricus $(O)$ in pure and mixed cultures in LAPTglu+gal (a) and LAPT-glu+fru (b) at $37^{\circ} \mathrm{C}$.

Croissance de $\mathrm{S}$. thermophilus $(\Theta)$ et $\mathrm{L}$. bulgaricus $(O)$ en cultures pure et mixte en milieu LAPTglu+gal (a) et LAPT-glu+fru (b) à $37^{\circ} \mathrm{C}$.

cose, galactose, lactose, fructose and sucrose. With the strains isolated from another source we observed that the mixed cultures of $S$. thermophilus and L. bulgaricus showed a different growth response than pure cultures, according to the sugar present in the medium. Further studies are required with combined mixed cultures of the strains isolated from the two different yogurt sources.

It is important to be aware of the sugar utilization behavior of mixed cultures when choosing starter bacteria for dairy fermen- tation. The identified interactions could form the basis of later studies on metabolic and genetic control of carbohydrate utilization in these strains isolated from commercial yogurt in Argentina.

\section{ACKNOWLEDGMENTS}

This work was partially supported by PID 309100/85 and grants from CIUNT 1987/1988. 


\section{REFERENCES}

Accolas J.P., Veaux M. \& Auclair J. (1971) Etude des interactions entre diverses bactéries lactiques thermophiles et mésophiles, en relation avec la fabrication des fromages à pâte cuite. Lait 51, 249-272

Accolas J.P., Bloquel R., Didienne R. \& Regnier J. (1977) Propriétés acidifiantes des bactéries lactiques thermophiles en relation avec la fabrication du yogurt. Lait 57, 1-23

Amoroso M.J., Manca de Nadra M.C. \& Oliver G. (1988) Glucose, galactose, fructose, lactose and sucrose utilization by Lactobacillus bulgaricus and Streptococcus thermophilus isolated from commercial yogurt. Milchwissenschaft 43 , 626-631

Bautista E.S., Dahiya R.S. \& Speck M.L. (1966) Identification of compounds causing symbiotic growth of Streptococcus thermophilus and Lactobacillus bulgaricus in milk. J. Dairy Res. 33 , 299-307

Driessen F.M., Kingma F. \& Stadhouders J. (1982) Evidence that Lactobacillus bulgaricus in yogurt is stimulated by carbon dioxide produced by Streptococcus thermophilius. Neth. Milk Dairy J.36, 135-144

Galesloot T.E., Hassing F. \& Veringa H.A. (1968) Symbiosis in yogurt. I. Stimulation of Lactobacillus bulgaricus by factor produced by Streptococcus thermophilus. Neth. Milk Dairy J. 22, 50-63

Hutkins R., Morris H.A. \& Mc Kay L.L. (1985a) Galactokinase activity in Streptococcus thermophilus. Appl. Environ. Microbial. 50, 777-780

Hutkins R., Morris H.A. \& Mc Kay L.L. (1985b) Galactose transport in Streptococcus thermophilus. Appl. Environ. Microbiol. 50, 772-776

Marshall M.E. \& Law B.A. (1984) The physiology and growth of dairy lactic acid bacteria. In : Advances in the Microbiology and Biochemistry of Cheese and Fermented Milk. (F.L. Davis \& B.A. Law eds.), Elsevier Applied Science Publishers, London, pp. 67-98

Mc Gregor J.V. \& White C.H. (1986) Effect of sweeteners on the quality and acceptability of yogurt, J. Dairy Sci. 69, 698-703

Mc Gregor J.V. \& White C.H. (1987) Effect of sweeteners on major volatile compounds and flavor of yogurt. J. Dairy Sci. 70, 1828-1834
Moon N.J. \& Reinbold G.W. (1976) Commensalism and competition in mixed cultures of Lactobacillus bulgaricus and Streptococcus thermophilus. J. Milk Food Technol. 39, 337-341

Nelson N. \& Somogyi M. (1966) Methods in Enzymology (S.P. Collowick \& N.O. Kaplan eds.) Academic Press, New York, vol. 8, pp. 7-9

O'Leary V.S. \& Woychik J.H. (1976) Utilization of lactose, glucose and galactose by a mixed culture of Streptococcus thermophilus and Lactobacillus bulgaricus in milk treated with lactase enzyme. Appl. Environ. Microbiol. 32, 89-94

Radke-Mitchell L. \& Sandine W.E. (1984) Associative growth and differential enumeration of Streptococcus thermophilus and Lactobacillus bulgaricus J. Food Prot. 47, 245-248

Raibaud P., Caulet M., Galpin J.V. \& Mocquot G. (1961) Studies on the bacterial flora of the alimentary tract of pigs. II. Streptococci : selective enumeration and differentiation of the dominant group. J. Appl. Bacteriol. 24, 285-306

Raya R.R., Manca de Nadra M.C., Pesce de Ruiz Holgado A. \& Oliver G. (1986) Acetaldehyde metabolism in lactic acid bacteria. Milchwissenschaft 41, 397-399

Schulz M.E. \& Hingst G. (1954) Beitrage sur Chemie des Yogurts. Milchwissenschaft 9, 330336

Thomas T.D. \& Crow V.L. (1984) Selection of galactose-fermenting Streptococcus thermophiIus in lactose-limited chemostat cultures. Appl. Environ. Microbiol. 48, 186-191

Thomas T.D. \& Mills O.E. (1981) Proteolytic enzymes of starter bacteria. Neth. Milk Dairy J. 35, 255-273

Tinson W., Hillier A.J. \& Jago G.R. (1982) Metabolism of Streptococcus thermophilus. I. Utilization of lactose, glucose and galactose. Aust. J. Dairy Technol. 37, 8-13

Turner K.W., Morris H.A. \& Martley F.G. (1983) Swiss-type cheese. II. The role of thermophilic lactobacilli in sugar fermentation. N.Z.J. Dairy Sci. Technol. 18, 117-123

Veringa H.A., Galesloot T.E. \& Davelaar H. (1968) Symbiosis in yoghurt. II. Isolation and identification of a growth factor for Lactobacillus bulgaricus produced by Streptococcus thermophilus. Neth. Milk Dairy J. 22, 114-120 